\title{
A Study on System for Reuse of Vacant Houses of a Historic Town by an Intermediate Organization Viewing from Habitants' Perception
}

\author{
Yumi Sumida and Nobuo Mishima
}

\begin{abstract}
This study focuses on vacant houses which become a social problem recently especially in local cities. The study area is a historic area in Japan called Hizen Hamashuku in which traditional townscape left and the house owners can receive subsidy from government to repair and renovate their buildings. Yet, vacant houses were increasing by low birthrate and aging. Thus, local habitants' recognition on reuse of vacant houses in the area was analyzed, and its problem was discussed to build a system of better use and management of the vacant houses. As a methodology, a questionnaire survey was conducted to clarify the idea of the owner of the vacant houses in the area. Then, basic situations of the vacant houses and wishes of the owners could be confirmed, and valuable data for utilization of the vacant houses for future of the area could be obtained. In addition, a questionnaire survey was conducted to NPO of the study area and persons who had moved to live into the area from the outside. Thus, we could discuss a system for reuse of the vacant houses from each viewpoint.
\end{abstract}

Index Terms - Local historic town, historic preservation area, reuse of vacant house, questionnaire survey, role of intermediate organization.

\section{INTRODUCTION}

\section{A. Background}

According to the survey by the Ministry of Internal Affairs and Communications of Japan, that is, "change of the number of the total houses and the number of the total households" issued in 2008, the number of vacant houses in Japan is approximately 7,600,000 houses. It is said that the rate of vacant houses is over $13 \%$ [1], and is expected that the rate will increase up to $43 \%$ by 2040 , and it is afraid that urban environment turns worse and residential comfort may be worse remarkably [2]. In addition, even in historic area with cultural heritage such as important traditional buildings preservation district designated by Japanese government (hereafter, ITBPD), vacant houses tend to increase and bring crises of communities. If vacant houses increase, townscape of the area became worse, and vigor of the whole town and value of ITBPD may be lost. Therefore, management system

Manuscript received December 5, 2016; revised February 5, 2017. This work was requested by the NPO "Mizumachikai" and Kashima city.

Yumi Sumida is with the Department of Civil Engineering and Architecture, Saga University, Saga city, Japan (e-mail: 16577009@edu.cc.saga-u.ac.jp).

Nobuo Mishima was with University of Tokyo, Tokyo, Japan in 1988 , 1990, and 1995 respectively. He also studied at Faculty of architecture and urban planning, Tech. Univ. of Vienna, Austria, as a scholarship student of Austrian government with Joint Study Program between two institutions, from October of 1990 to March of 1993. He is now with Graduate School of Science \& Engineering, Saga University, Saga city, Japan (e-mail: mishiman@cc.saga-u.ac.jp). to promote use of vacant houses is needed also viewing from security, hygiene, and townscape. The increase of vacant houses is caused by low birthrate and aging, so the use of vacant houses which is currently carried out and the study for management system of vacant houses are still in trial and error.

\section{B. Research Review}

Reuses of vacant houses have been currently carried out in every ITBPD, so there are many researchers who research on vacant houses. As previous studies relevant to our study, we can categorize into three types: studies on organizations who reuse vacant houses, studies on management system to promote use of vacant houses, and studies on actual condition of vacant houses.

As per studies on organizations, Ito and Shimizu reveal that subleases with limitation of lease term by local organizations can succeed in reduction of number of vacant stores, and that it brings people who are interested in the sublease and also leads the areas to revitalization [3]. Goto and Kawashima mention some consideration points to local organization rather than management system to promote use of vacant houses [4]. Sakoda and Kato introduce that private organization and local government in Yame city of Fukuoka take great care of immigrants from the before and to the after of their moves [5].

Regarding management system to promote use of vacant houses, Sakai categorizes activities of local organizations which renovate traditional houses in Japan and discuss practical methods for renovation of traditional houses [6]. Tujimoto and Fujita clarify organization system and significant points to renovate vacant houses through taking questionnaire survey to the immigrants of Imai-machi, Nara prefecture [7].

As for the actual condition of vacant houses, there are numerous researches. Ohuchi et al. reveal causes of vacant houses and efficiency of renovation projects of vacant houses by questionnaire survey to house owners [8]. Matsuoka et al. mention the possibility of housing supply by vacant house owners supply vacant houses by vacant house owners to accept people coming from another place [9]. Yamazoe and Kanki suppose to be able to stop increasing vacant houses by measures in process of becoming vacant houses [10]. Yoshida et al. mention that vacant houses do not always effect townscape and that consciousness of house owners to vacant houses do not relate to maintenance of vacant houses [11]. Yamazoe et al. show that local government staffs have high consciousness to vacant houses and that many vacant houses are used as public facilities [12]. 


\section{Aim of Study}

In this study, we focus on an area with historic townscape as a local town which has grants for repairing and landscaping of buildings. Then, the aim of study is to make clear a management system for an intermediate organization to reuse vacant house viewing from habitants' perception.

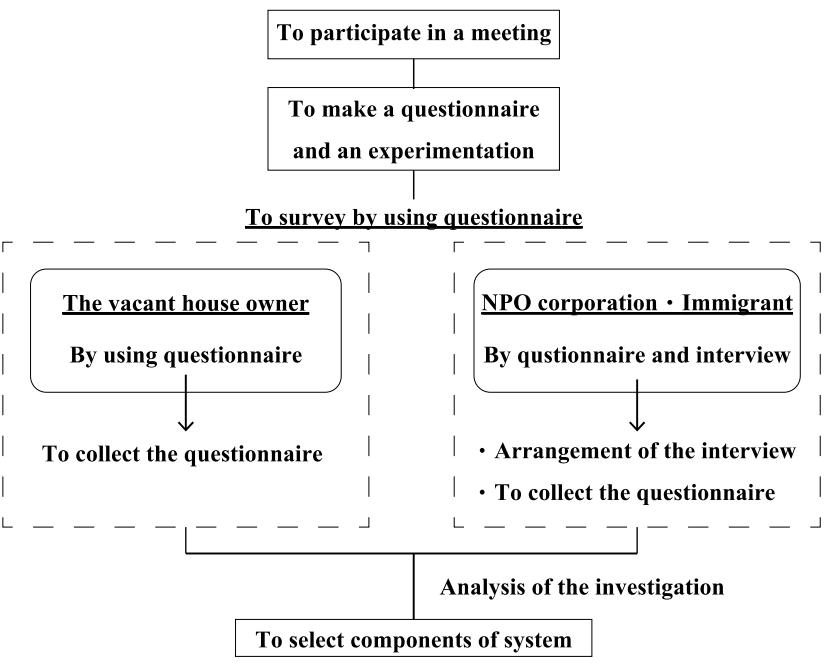

Fig. 1. Procedure of the study. (hereafter, HHS) in Kashima city of Saga prefecture, Japan, because its population is aging and the number of vacant houses are increasing although the area is preserved and subsidized as ITBPD and also supported with a townscaping project by the Ministry of Land, Infrastructure, Transport and Tourism (hereafter, MLITT). Besides, Kashima city authority entrusts a survey of the vacant house to NPO "Mizumachikai" (hereafter, the NPO) which works for community building ("machidukuri" in Japanese) in the area. Therefore, considering the situation, this study conducts a questionnaire survey to the house owners of the vacant houses and to staffs of the NPO following the study procedure as shown in Fig. 1.

\section{OUTLINE OF THE SURVEY AREA}

In HHS, there are two ITBPDs which have different characters as shown in Figs. 2 and 3. One of the ITBPDs is Hamashozumachi -hamakanayamachi district (hereafter, Shokin district) characterized as a local town facing to the Ariake Sea with a lot of wooden thatched townhouses and tile-roofed town houses, and partially also as a fisherman village. Another one is Hamanakamachi-happongishuku district (hereafter, Hasshuku district). This area has durability of traditional buildings and Sake Breweries.

\section{Methodology}

First, the study set a study area called Hizenhamasyuku

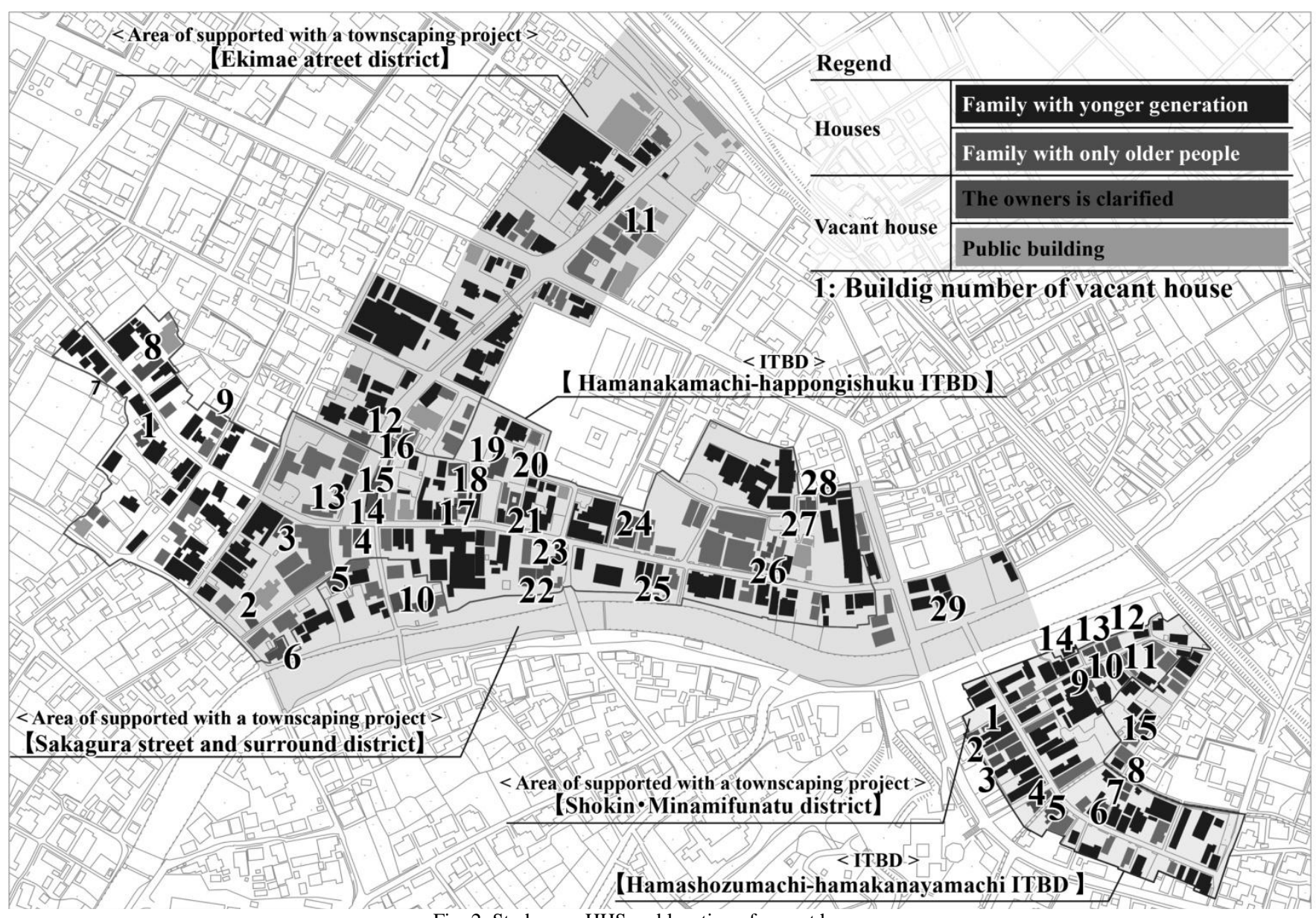

Fig. 2. Study area HHS and location of vacant houses.

Fig. 2 also indicates vacant houses in the area. This figure was created by the NPO and Kashima city during 2012 to 2013. The vacant houses they surveyed are in Shokin and Hasshuku districts, and additionally in Ekimae street district 
(hereafter, Ekimae district) and Sakagura street district (Sakagura district) which are being improved by a subsidy system of the MLITT. According to the map, number of vacant houses is 53, and it is expected that the number of the vacant houses will be increased because of a lot of old elderly persons in the ITBPDs, then the townscape might be worse. In the future, to maintain the townscape should be difficult. Hence, we must solve the problem as soon as possible.

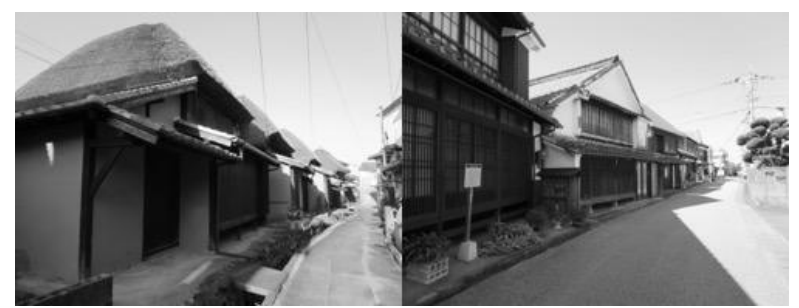

(a) Thatched houses in Shokin.

(b) Street view of Hasshuku

Fig. 3. Photos of the study area.

\section{SURVEY AND ANALYSIS OF THE STUDY AREA}

Generally speaking, there are mainly two parties to solve the problem of vacant house. One is government and another is private organization. Reusing vacant houses should be managed systematically. In case of HHS, reuse of vacant houses has been gradually discussed and progressed by local habitants and the NPO. Kashima city is also considering the problem to vitalize the area and to enhance tourism of the city.

Therefore, we built an idea of management system for vacant houses as shown in Fig. 4. Namely, NPO manages reuse of vacant houses between the vacant house owner and immigrants in cooperation with local government and university. Thus, the opinions to the above-mentioned system are collected, arranged, and analyzed.

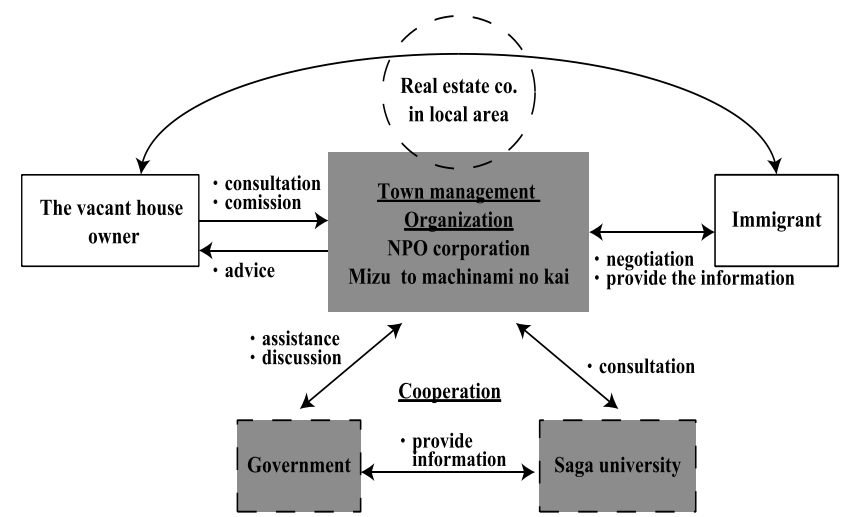

Fig. 4. An idea of the system to know its efficiency.

The house owners surveyed in this study are extracted from the vacant houses of Fig. 2. Hence, the survey area is composed of the two ITBPDs and their surroundings where the house owners can receive subsidy to repair or to build their houses. There are 46 and 7 vacant houses in the ITBPDs and in the surroundings, respectively.

The questionnaire is conducted to the vacant house owners, the NPO staffs, and the persons who moved into the study area. Table I and II show results of distribution of the questionnaire to the vacant house owners and to the NPO staffs and the immigrants, respectively.

TABLE I: DISTRIBUTION OF QUESTIONNAIRE TO VACANT HOUSE OWNERS

\begin{tabular}{llll}
\hline $\begin{array}{l}\text { Distribution } \\
\text { period } \\
\text { (From October to } \\
\text { November, 2015) }\end{array}$ & $\begin{array}{l}\text { Direct } \\
\text { distribution }\end{array}$ & $\begin{array}{l}\text { Mail } \\
\text { distributi } \\
\text { on }\end{array}$ & Total \\
\hline $\begin{array}{l}\text { The number of } \\
\text { distribution }\end{array}$ & 25 cases & 13 cases & $\begin{array}{l}\text { cases } \\
\text { The number of } \\
\text { response }\end{array}$ \\
\begin{tabular}{l} 
Response rate \\
\hline
\end{tabular}
\end{tabular}

TABLE II: DISTRIBUTION OF QUESTIONNAIRE TO NPO STAFFS AND IMMIGRANTS

\begin{tabular}{llll}
\hline \hline $\begin{array}{l}\text { Distribution } \\
\text { period } \\
\text { (November, }\end{array}$ & NPO & Immigrant & Total \\
2015) & $49 *$ cases & 12 cases & 66 \\
\hline Total number & 16 cases & 6 cases & 22 \\
$\begin{array}{l}\text { The number of } \\
\text { the distribution }\end{array}$ & 16 cases & 4 cases & $\begin{array}{l}\text { cases } \\
\text { The number of } \\
\text { response }\end{array}$ \\
Response rate & $100 \%$ & $67 \%$ & $\begin{array}{l}\text { cases } \\
91 \%\end{array}$ \\
\hline \hline
\end{tabular}

* The number of the distribution

Distribution period of the questionnaire to the vacant house owner was from October to November, 2015. The questionnaire was distributed to 51 vacant house owners whose addresses were known by mail. If one vacant house owner had some vacant houses, the same number of the questionnaire shirts should be sent to the vacant house owner. The contents of questionnaire were: 1) current use of the house, 2) future plan of use, and 3) management system of the house, especially on possibility of the NPO.

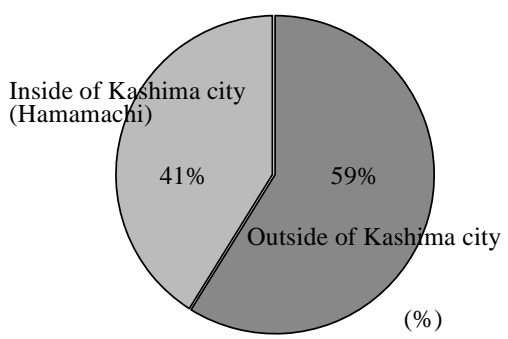

(a) The present address of vacant house owners.

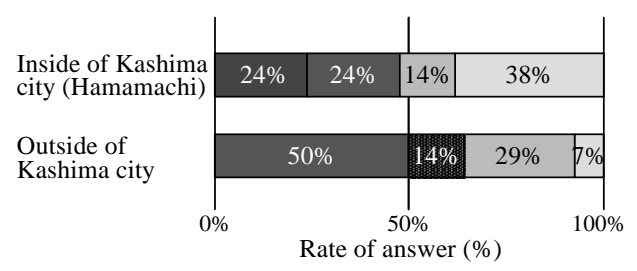

Once a week house cleaning, ventilating, and checking.

Once a month house cleaning, ventilating, and checking.

Once a year house cleaning, ventilating, and checking.

Visit in a long vacation

Request traders and acquaintances

$\square$ Others

(b) The management situation of the vacant houses.

Fig. 5. Current living place of the vacant house owners 


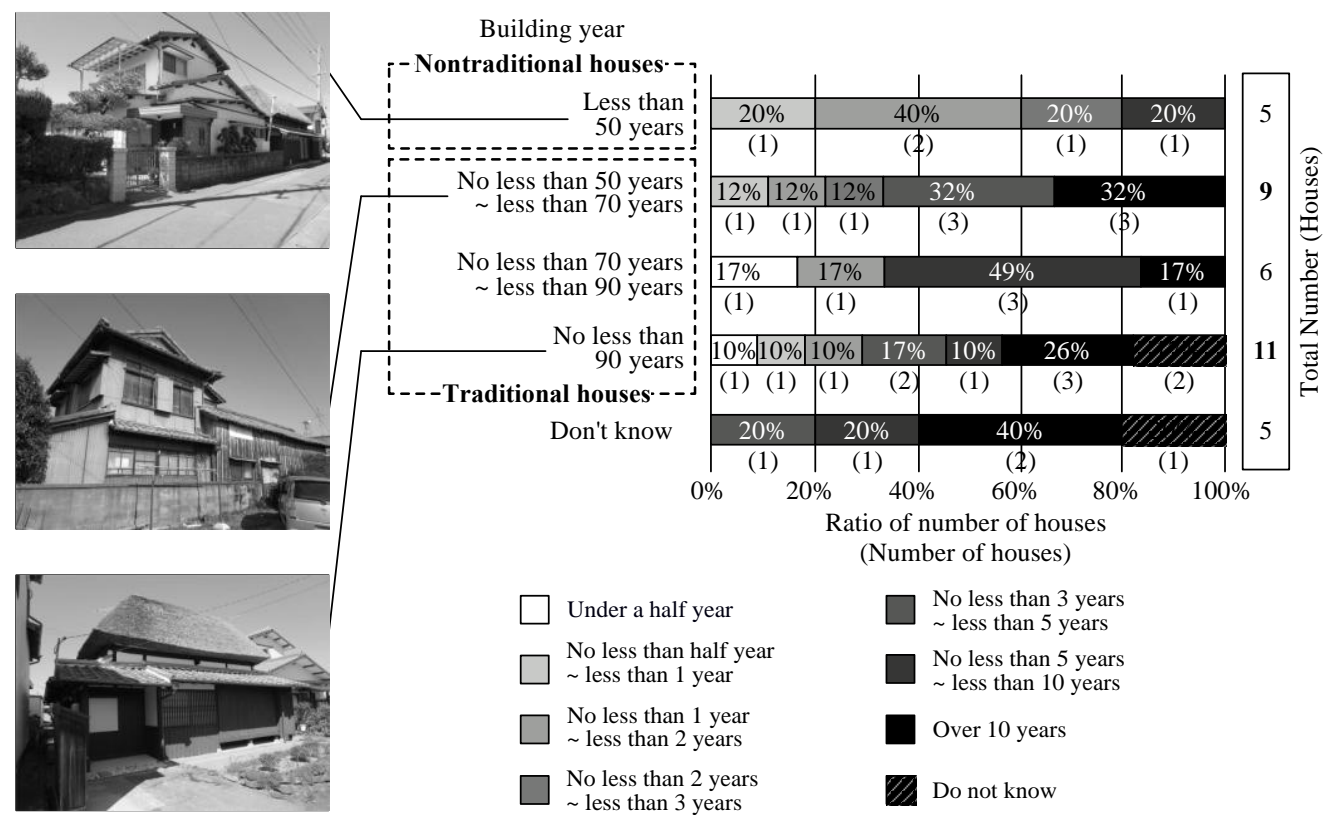

Fig. 6. Building years and period of vacant houses.

Distribution period to the NPO staffs and the immigrants was November, 2015. The questionnaire was handed directly and collected to better the response rate. The contents of questionnaire were: 1) current situation of HHS, 2) problems in the town, 3) idea of reusing vacant houses, and 4) management system of the houses. Besides, to the immigrants, the reason why they wanted to move into the area was questioned. In parallel, we conducted also interview to whom we could request. As per the interview, we could obtain from 5 NPO staffs and 2 immigrants.

In this survey, the number of response of questionnaire to the NPO staffs and the immigrants is not enough, so it has no statistical meaning. Yet, the survey results are meaningful enough to know their idea by combining the questionnaire survey and the interview survey.

\section{Results of SuRVey to VACANT House OWNers}

\section{A. Analysis of Vacant Houses and Owners}

According to the analysis, the highest answer of building years of vacant houses was more than 90 years standing in the area. Next was from 50 to 70 years. Comparing the building years and the terms of vacant houses, older building year brings longer vacancy. As per the owner's current living place, the rate of vacant owners who lived in Kashima city including Hamamachi (administrative name of the survey area) was more than half. Regarding the situation of managements, it became obvious that the owners living in or near the study area could manage their vacant houses constantly. On the other hand, the owners living far from the area could not manage and there were several vacant houses without cares as shown in Figs. 5 and 6.

Next, as per anxieties, the owners checked almost all factors, but "fire" and "become too old" were especially highly checked as shown in Fig. 7. Moreover, older adults checked more intensively on "becoming too old" and "to keep management of vacant house." Comparing with the age and living places, the owners living far had more anxieties than the vacant owners living in Hamamachi and Kashima city.

The answers why remaining vacant houses were mainly "nobody succeeds the houses or the lands ( 5 people)" as shown in Fig. 8. This answer was a little bit much more than the other answers. Additionally, the most answer was "others (12 people)."

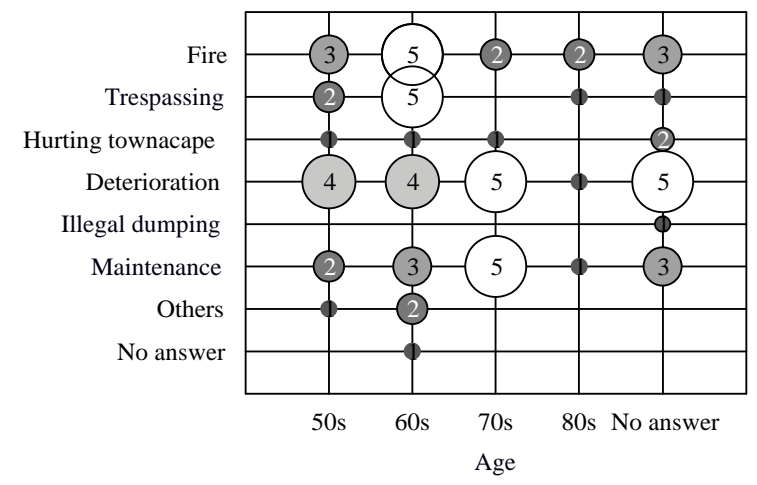

Fig. 7. Answers on anxieties in owning vacant houses.

According to free answers on the reason of remaining vacant houses, the reasons were, e.g., "Living in a nursing home for the elderly at this moment, "Planning to move in", "Planning to conduct vacation rental" and so on. These answers showed that they were willing to reuse their vacant houses. We show the other reasons in Table III.

\section{TABLE III: OTHER REASONS}

\begin{tabular}{l}
\hline Reason \\
- I work in other land, but I will live in from the next year. \\
- I will do a private home providing meals and lodging in future \\
- People left house recently \\
- I put baggage and use it now. \\
- Owner enters facilities \\
- It is the thing which I got as a substitute for debt \\
- I live in other places independently
\end{tabular}




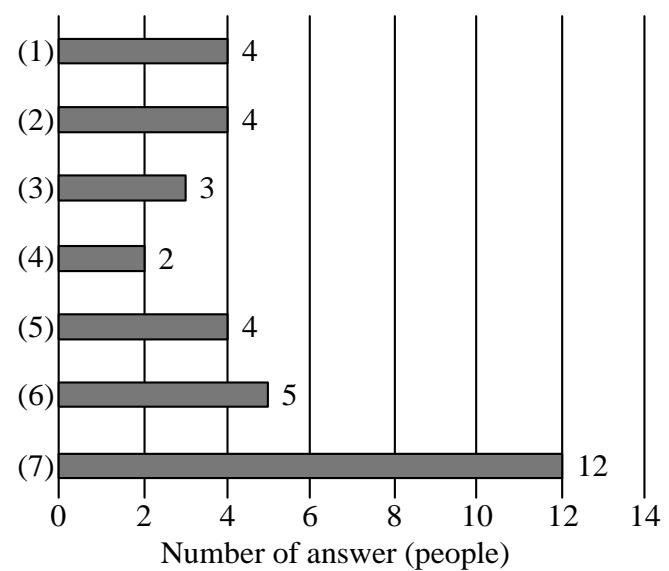

(1) Cannot live, because the house is deterioration

(2) To live in the other place with family

(3) Want to put the old furniture

(4) Do not know how to reuse

(5) Now, cannot live alone

(6) No successors of house

(7) Others

Fig. 8. Answers on reason why remaining vacant houses.

\section{B. Will to Utilize of the Vacant Houses and Recognition of Measures}

As per the answers to question about increase of the vacant houses in HHS, persons over 60 years old think that it is big problems and actually feel that it influences the historic townscape. Most of 50s and 60s think that all habitants of HHS should work to solve the problem together. Yet, there are some opinions that it is no problems (Fig. 9).

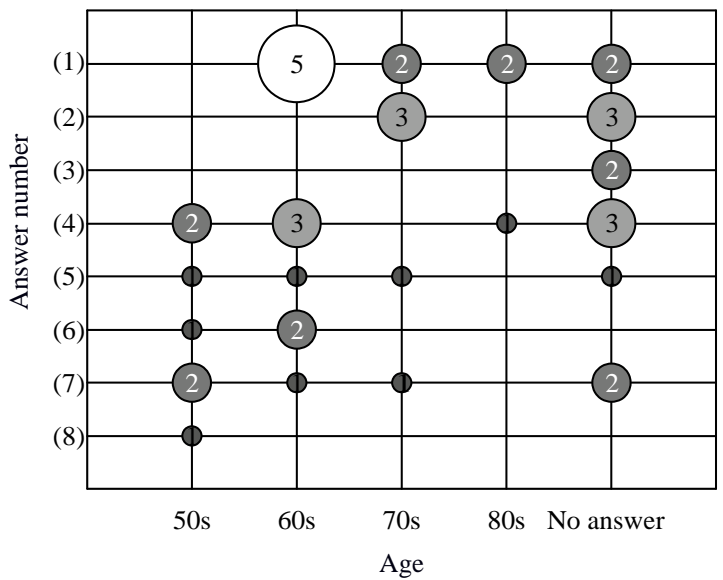

(1) Big problems

(2) Influence to the townscape

(3) Rather be solved by anybody

(4) Must be solved by the whole town

(5) Rather be demolished by anybody

(6) Without problems

(7) Others

(8) No answer

Fig. 9. Answers on situation of vacant houses.

Next, as for the vacant houses the owners themselves own, mainly people over $60 \mathrm{~s}$ who think that increase of the vacant houses in HHS is a big problem answer that they want to cooperate in solving the problem. On the other hands, also some people feel it without problems (Fig. 10).

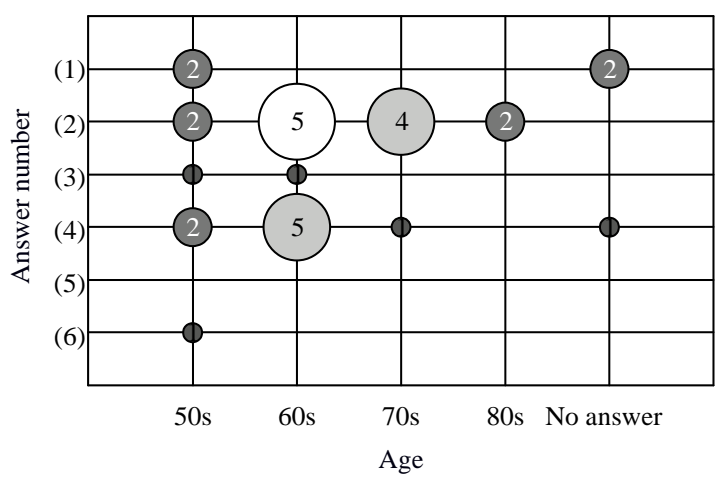

(1) Rather be solved because spoiling townscape

(2) Should be reused for revitalization of the town

(3) Should not stand in the preservation district

(4) Without problems

(5) Others

(6) No answer

Fig. 10. Answers on owning vacant houses.

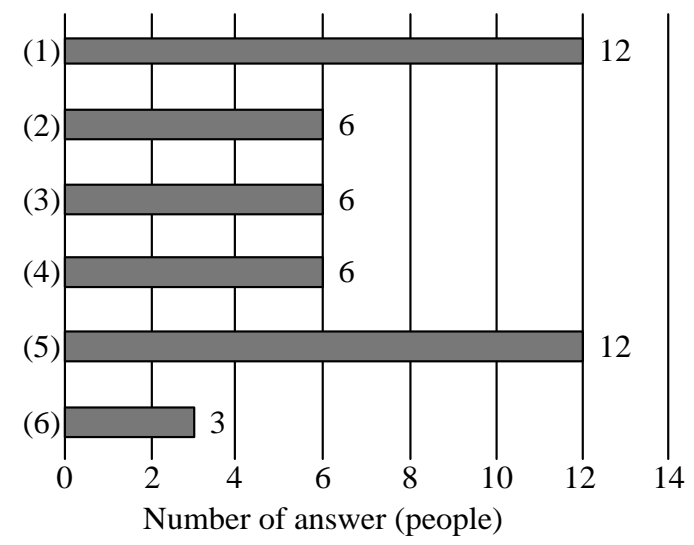

(1) Want to keep having

(2) Want to rent

(3) Want to dismantle

(4) Want to rent the whole land

(5) Do nothing for a while

(6) Do not know how to reuse

Fig. 11. Answers on the owner's intention for future.

Regarding intentions to the vacant houses they own (Fig. 11), more than half owners of vacant houses intend to reuse it without living like "reusing and breaking up for rental houses (18 people in total)," "selling it with land (6 people in total)," "conversion to parking ( 2 people in total)." On the other hand, the intentions for living are like "planning to move in (5 people in total)." "now living in a nursing home for elderly people (2 people in total)".

As to the measures for the vacant houses (registration system of vacant houses, subsidies for reusing of vacant houses and so on), only no more than half owners know. Although 64\% people want to reuse the vacant houses among the people who know the measures, almost all vacant houses still remain standing as they are for long terms. As results, a lot of vacant houses in HHS are not reused yet (Fig. 12).

Viewing from reuse of vacant houses, we think that the persons who answered "no people will succeed the houses and lands," "not knowing how to reuse vacant houses," "living in the other place with my family" and so on will 
reuse the vacant houses if we contact the person and can negotiate well. Moreover, even the house nobody lives because too old can be hopefully reused after grasping its conditions. On the other hand, the owners who answered "keeping furniture in the vacant houses ( 3 cases)" did not live in but used like storage, and the owners who answered "could not live alone now" did not live in. Yet, there are some possibilities that they will come back and live in, so we can hardly say that these houses are vacant (Table IV).

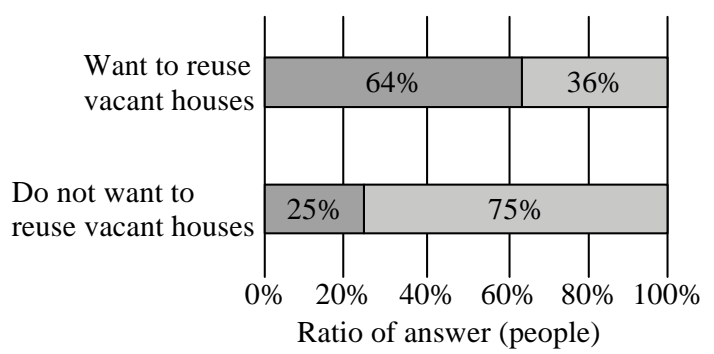

Know

Do not know

Fig. 12. Recognition of unoccupied house measures.

TABLE IV: REASON OF WILLING TO USE OF NOT TO USE Reasons to reuse

- I will repair some or all and want to use it in a different use.

- After having dismantled vacant houses, I make the parking lot or want to sell it.

- I want to sell every land because I cannot maintain it.

- Because there is no successor, I want to sell every land.

- Because it is not facing a road, I want to use it without buildings.

Reasons not to reuse

- I am going to live in future.

- Because the owner enters facilities.

- Because I do not know a consultation window and the system.

- I want to lend it until I sell it.

\section{A Proposal of System to Reuse Vacant Houses}

More than half owners of vacant houses know that NPO was discussing about reuse of vacant houses. Yet, 14 people among 17 people who answered "know" was living in Hamamachi or in Kashima city, the rest three people were living out of Kashima city. Regarding the meeting, the people who live out of Kashima city can scarcely know anything.

Next, as to the question that the NPO conducted to sell or rent vacant houses as a mediator, 10 people agreed. Yet, 9 people did not agree with it and 14 people answered "no idea." The cause was that the NPO was not well known by the person living out of Kashima city. The reasons for it were "willing to reuse the vacant houses for keeping townscape (13 people)," "not willing to sell or rent to unknown persons (7 people)." Also, there were some questions on trustworthiness of the NPO such as "if they act sensibly," and opinions against it because they did not know about the NPO. Hence, it is necessary for the NPO to be well-known and credible as a mediator to the owners also living out of Kashima city.

\section{AbSTRACT AND Clarify Points to BUILD THE SYSTEM}

Here in this chapter, it is clarified what the NPO is requested and what they can do in creating a management system for reusing vacant houses through a survey on perceptions of the NPO members and new habitants, also grasping present conditions of the NPO. Yet, in the above-mentioned questionnaire survey we could not get enough number of answer from members of the NPO (only 16 people) and new habitants (only 4 people) to get statistical meanings. Therefore, we additionally conduct an interview survey to both of the NPO's main staffs and some new habitants. This interview can make us concretely know what and how they are thinking, so this survey is very significant. Thus, we abstract and clarify points to build the system for vacant houses analyzing results of the questionnaire and the interview.

\section{A. Present and Future Problems of HHS}

All of the interviewees pointed out as followings: The habitants are aging so that HHS is rather depopulated, and that it had brought many problems, for instance, depressing activities of the NPO, increasing vacant houses, making interchanges between communities and new habitants less, and so on. There were also differences of recognition for activation of town, sightseeing, and treatment to tourists. As future problems, beside solving the above-mentioned problems, they need to upgrade supports for new habitants, to create a system for financially independent town from supports from administration.

\section{B. Present Conditions and Problems of the NPO}

The main staffs of the NPO mentioned as followings: Only part of the NPO members are aggressive to attend their meetings and events, so not all of the members and the habitants can grasp information and activities of the NPO. It becomes obvious that the whole NPO or local communities cannot grasp details of working of NPO. Moreover, the main staffs of the NPO are from the outside of two ITBPDs. Besides, the issues begin to affect reliability of the NPO because they can have hardly solved different opinions and problems are remaining.

As future problems, the NPO must review the system of the NPO by itself and have a common sense as one organization, and it is necessary to work for their activities in cooperation with other organizations.

\section{DisCUSSION ON SYSTEM FOR REUSING VACANT HOUSES}

According to the analysis, it has become obvious that three parties, that is, house owners, the NPO, and new habitants, are willing to make positions in charge not only of the reuse of vacant houses but also of the communication between new habitants and local inhabitants. Additionally, according to the opinions on a system for reuse of vacant houses, the NPO has limitations of the things corresponding to vacant house owners and applicants of new habitants as an intermediate organization, because burden on the NPO is too heavy. Thus, after rearranging of the opinions about system for reuse of vacant houses, we assume a system and roles, and considering the system for reuse of vacant houses of a historic town by an intermediate organization viewing from habitants' perception (Table V).

As per the system, the NPO should work for measures to vacant houses while NPO continues to work for the other 
activities. As for the roles, the NPO can manage the information of vacant houses and support to new habitants like "consultant," can survey on vacant houses and progress the reuse such as "intermediate and agent," and can encourage communication among local habitants and new habitants like "communicator."

These three positions should be clearly distinguished in the organization of the NPO. In the system in which the habitants' perceptions are reflected, the NPO should work as a main body. Yet, with the help of local government, the task of the NPO should be reduced. In the cooperation of the residents such as the meeting of the traditional building owners, preservation should be promoted appropriately. On the other hands, to advance the system in future, the NPO needs to review their organization and to play the roles we propose smoothly.

TABLE V: HABITANTS' PERCEPTION TO SYSTEM AND ROLES

\begin{tabular}{|c|c|c|}
\hline & Comments to the system & Request to the NPO \\
\hline 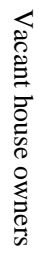 & $\begin{array}{l}\text { NPO should work outside of } \\
\text { HHS. }\end{array}$ & $\begin{array}{l}\text { To support new habitants with } \\
\text { government. } \\
\text { To provide appropriate } \\
\text { information to new habitants. } \\
\text { To give advices, to announce } \\
\text { local charms, and to protect the } \\
\text { townscape }\end{array}$ \\
\hline 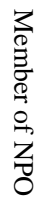 & $\begin{array}{l}\text { The NPO should work as a main } \\
\text { body and the other organizations } \\
\text { help the NPO. } \\
\text { Not too heavy burden of the } \\
\text { NPO. }\end{array}$ & $\begin{array}{l}\text { To provide appropriate } \\
\text { information and to advise } \\
\text { house owners. } \\
\text { To support to immigrants. } \\
\text { To call immigrants. }\end{array}$ \\
\hline 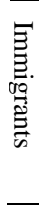 & $\begin{array}{l}\text { The NPO should provide } \\
\text { appropriate information. }\end{array}$ & $\begin{array}{l}\text { To get qualification of real } \\
\text { estate and to corporate with } \\
\text { agents. } \\
\text { To communicate with local } \\
\text { habitants and change their } \\
\text { opinions. }\end{array}$ \\
\hline
\end{tabular}

\section{CONCLUSION}

In this research, we investigated the current situation of vacant houses and confirmed intentions of vacant house owners by conducting a questionnaire survey to the owners who have vacant houses in HHS, then valuable data for planning to reuse the vacant houses in future could be obtained. Moreover, thanks to perform a questionnaire survey to vacant house owners, the staffs of the NPO, and the new habitants, we could know the points to create a system for reuse of vacant houses by an intermediate organization in a historic town viewing from habitants' perception. However, comparing with the system which organization of Yame works to reuse vacant houses, there are many insufficient points to be applied, so the system proposed in the study should be revised.

Considering the problems especially cause from the study method such as few response of questionnaire and only one study area surveyed, this study has limitation to conclude, so more surveys should be conducted particularly for the whole town where the survey was not conducted in this study and more comparisons should be done with the other historic areas. Besides, a new regime for vacant house by the middle organization should be examine practically.

\section{ACKNOWLEDGMENT}

This study is supported by JSPS KAKENHI Grant Number JP16H04478 and also by the consignment study from Kashima city on vacant buildings in the target place. We would like to appreciate the NPO, its staffs, and all of the habitants for their assistance to the survey and thank to Kashima city authority for their providing data.

\section{REFERENCES}

[1] Ministry of Internal Affairs and Communications, Change of the Number of the Total Houses and the Number of the Total Households, 2008.

[2] O. Nagashima, "Japan which is eroded by vacant houses," Poplar Company, 2014, pp. 1-174.

[3] S. Ito and Y. Shimizu, "Study on action of the unoccupied house utilization as local resources," Research Report of Kinki Branch, Architectural Institute of Japan, vol. 54, pp. 357-360, 2014.

[4] M. Goto and K. Kawashima, "A study on system for reuse of vacant houses of important traditional buildings preservation district: Focus on organization which working on a policy to reuse vacant houses and their working," Research Report of Kanto Branch, Architectural Institute of Japan, vol. 79, pp. 169-172, 2009.

[5] T. Sakoda and K. Kato, "A study on propulsion organization of Utilize vacant house in Yame-Fukushima preservation district for groups of historical of building: Focusing on activities of Non-Profit organization "Yame Machi-ya Saisei Oendan," Research Report of Kyusyu Branch, Architectural Institute of Japan, vol. 49, pp. 421-424.

[6] K. Sakai, "A study of role and problem of the private organization for renovating of old folk house in important preservation districts for groups of traditional buildings -In case of "Machinami-Yanami-Kenkyusho" Based on Sasayama City, Hyogo Prefecture- ," M.S. thesis, Graduate School for Creative Cities, Osaka City Univ., Osaka, Japan, 2015.

[7] Y. Tsujimoto and S. Fujita, "A study of the vacant dwelling in townscape conservation MACHIDUKURI: A case study of Imai Town, Kashihara City, Nara Pref," Research Report of Kinki Branch, Architectural Institute of Japan, vol. 46, pp. 369-372, 2006.

[8] Y. Ohuchi, K. Murakami, M. Nakazono, S. Shigenaga, Y. Murata, and K. Shimado, "A study on possibility of renovation system for vacant house in the central area of local city: A vacant house owner's intentions of reuse it as rental house (Form3)," Research Report of Chugoku Branch, Architectural Institute of Japan, vol. 28, pp. 869-872, 2005 .

[9] M. Matuoka, T. Hirata, T. Honda, K. Yamashita, and K. Jinno, "Realities of vacant house and vacant house owner seen from questionnaire," Summaries of Technical Papers of Annual Meeting, Vol. 2009, pp. 487-488, 2009.

[10] K. Yamazoe and K. Kanki, "Study on vacant dwellings and vacant land in the historical preservation district: Through a case study in Yuasa-cho," Summaries of Technical Papers of Annual Meeting, Vol. 2000, pp. 1019-1020, 2000.

[11] N. Yoshida, H Mano, Y. Kano, and M. Manabe, "Study on owner's attitude and maintenance on vacant house at the conversation district of traditional structures: case of TAKEHARA-CHIKU," Research Report of Chugoku Branch, Architectural Institute of Japan, vol. 27, pp. 773-776, 2004.

[12] K. Yamazoe, H. Tanada, and K. Kannki, "Vacant buildings and Vacant lands in preservation areas of hstorical townscape and the utilization Part 1 : Present situation and utilization cases of vacant buildings and vacant lands in preservation areas of historical buildings," Summaries of Technical Papers of Annual Meeting, vol. 2001, pp. 849-850, 2001. Available:

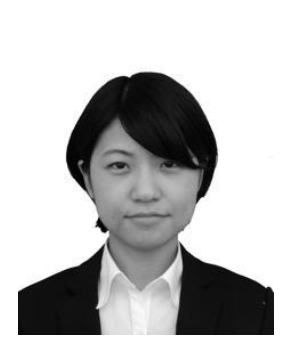

Sumida Yumi was born in Yamaguchi, Japan, on May 8 of 1993. She received the B.E. degrees in urban engineering from Saga University, Japan in 2016.

Sumida Yumi had worked with INTER MEDIA Atelier in August 2014, Takao Shiotsuka Atelier in September 2016 and will work with Nikken Sekkei in January 2017. Furthermore, she had participated in several workshop which is Asian Rim Internationai Seminar 2015 in Kashima, ASIAN Rim International Seminar 2016 in Kazgasa and Asian Rim Internationai Seminar 2016 in Kashima. author's major field of study should be lower-cased. 
Nobuo Mishima was born in Fukuoka, Japan, on May 11 of 1964. He entered the Univ. of Tokyo in April of 1984 and belong to the department of urban engineering. He received the B.E., M.E., and D.E. degrees in urban engineering from the Univ. of Tokyo, Japan in 1988, 1990, and 1995 respectively. He also studied at Faculty of architecture and urban planning, Tech. Univ. of Vienna, Austria, as a scholarship student of Austrian government with Joint Study Program between two institutions, from October of 1990 to March of 1993.

He worked at Eto Shinchi Architecture Atelier in Vienna and in Osaka, Japan, as a Technical Staff from 1992 to 1994. Since he was graduated from the doctor course of University of Tokyo, he has been with Saga University, Japan, as Lecturer from 1995 to 1998, Assistant Professor from 1998 to 2007, Associate Professor from 2007 to 2013, and Professor from 2013. Moreover, he got the Qualified Architect of First-class in Japan on February 7 of 1997.
Prof. Dr. Arch. Mishima belongs to Arch. Inst. of Japan (AIJ), The City Planning Inst. of Japan (CPIJ), Assoc. of Urban Housing Sci. (AUHS), Japan Inst. of Archt. (JIA), Saga Archt. Assoc. (SAA), Int. Assoc. of Lowland Technology (IALT), and Korea Contents Assoc. (KoCon). His main research interests include urban planning and design, and architectural design. He has many awards from several institutions, such as two Achievement Award by AUHS in 2010 and 2012, Best Presentation Award of the Int. Conf. of Habitat Eng. and Design in 2012. He has also many publications of books, journal papers and proceedings paper of conferences 